\title{
To study the effect of fym, coirpith, vermicompost, humic acid and panchagavya on growth and yield of mint (Mentha arvensis.)
}

\begin{abstract}
A field experiment was conducted during 2017-2018 at RVS Padmavathy College of Horticulture, Sempatti. field experiment was conducted during 2017-2018 to study the effect of organic manures on growth of mint. A significant increase in plant height, secondary brnaches, leaf length, leaf width, leaf yield per plant and leaf yield per hectare were observed with the application of FYM, Coirpith, Vermicompost, Humic Acid, and Panchagavya. Application of Vermicompost $\left(2.5\right.$ tha $\left.^{-1}\right)+$ Humic Acid $(0.3 \%)$ significantly increased growth and yield of mint.
\end{abstract}

Keywords: organic, panchagavya, vermicompost, humic acid and mint
Volume 2 Issue $6-2018$

\author{
Suresh V,' J Preethi Fetricia, ${ }^{2}$ V Saranya, ${ }^{2} \mathrm{~S}$ \\ Sarithra, ${ }^{2}$ K Tamilselvan ${ }^{2}$ \\ 'Assistant Professor, RVS Padmavathy College of Horticulture, \\ India \\ ${ }^{2}$ RVS Padmavathy College of Horticulture, India
}

Correspondence: Suresh V, Assistant Professor, RVS Padmavathy College of Horticulture, India Email sureshbossI22@gmail.com

Received: October 03, 2018 | Published: December 19, 2018

\section{Introduction}

Mints are a group of perennial herbaceous plants belonging to the family Lamiaceae which yield essential oil on distillation. The various species of mints which are commercially cultivated in different parts of the world viz., Japanese mint or corn mint or Field mint (Mentha arvensis), pepper mint (M. piperita L.), spearmint or garden mint or Lambmint (M. spicata L.) and bergamot mint or orange mint ( $M$. citrate Ehrh.). The leaves can be eaten raw or cooked and are used as a flavoring in salads or cooked foods. They have a strong taste of peppermint. A herb tea is made from the fresh or dried leaves. This mint is a source of Japanese menthol, used to flavor candies, drinks, etc. An essential oil from the plant is used as a flavoring in sweets and beverages. The leaves contain about $0.2 \%$ essential oil. The plant is used as an insect repellent. Rats and mice intensely dislike the smell of mint. According to Manivannan and Kudiyarasi, (2010) application of vermicompost@2kg+humic acid 2per cent foliar spray recorded the maximum plant height $(241.39 \mathrm{~cm}$ on $150 \mathrm{DAP})$, more number of lateral (45.54), leaves per lateral, soluble protein, total phenols $\left(6516.48 \mu \mathrm{g} \mathrm{g}^{-1}\right)$ and gymnemic acid $\left(807.13 \mathrm{mg} 100^{-1}\right.$ dry weight) in gymnema. Natural balance should be maintained at all costs for the productivity of the land for obtaining increased yields. Keeping in view the above facts, the present investigation was undertaken to ascertain the effect of organic manures on growth and yield of mint. The integration of organic manures will lead to the build up of soil fertility, increased in crop productivity with concomitant nutrient balances besides minimizing the pollution hazards as well as the fertilizer bill. Hence the present study aims.

\section{Materials and methods}

Three plants in each treatment per replication were selected at random and utilized for recording observations on the following characters and mean values were subjected to statistical scrutiny as suggested by Panse et al. ${ }^{1}$ (Table 1 ).

\section{Results}

The combined effect of organic manures on plant height exhibited highly significant influence. The results showed that, the treatment
$\mathrm{T}_{5}$ (Vermicompost@2.5tha ${ }^{-1}+$ Humic Acid@0.3\%) registered higher plant height (22.8 cm respectively) as compared to other treatment. It was followed by the treatment $\mathrm{T}_{6}$ (Vermicompost@ 2.5tha1+Panchagavya@3\%). However, the treatment (control) recorded least plant height $14.30 \mathrm{~cm}$ (Table 2).

Table I The experiment was laid out in completely randomized block design (CRD) with seven treatments replicated thrice

\begin{tabular}{ll}
\hline Treatments & Details \\
\hline $\mathrm{T}_{1}$ & FYM $\left(25 \mathrm{tha}^{-1}\right)+$ Humic Acid $(0.3 \%)$ \\
$\mathrm{T}_{2}$ & FYM $\left(25 \mathrm{t} \mathrm{ha}^{-1}\right)+$ Panchagavya (3\%) \\
$\mathrm{T}_{3}$ & Coirpith $\left(5 \mathrm{t} \mathrm{ha}^{-1}\right)+$ Humic Acid (0.3\%) \\
$\mathrm{T}_{4}$ & Coirpith $\left(5 \mathrm{tha}^{-1}\right)+$ Panchagavya (3\%) \\
$\mathrm{T}_{5}$ & Vermicompost $\left(2.5 \mathrm{tha}^{-1}\right)+$ Humic Acid (0.3\%) \\
$\mathrm{T}_{6}$ & Vermicompost $\left(2.5 \mathrm{t} \mathrm{ha}^{-1}\right)+$ Panchagavya (3\%) \\
$\mathrm{T}_{7}$ & Control \\
\hline
\end{tabular}

Table 2 Effect of organic manures on plant height $(\mathrm{cm})$ of mint (Menthaarvensis L.)

\begin{tabular}{lllll}
\hline Treatments & $\begin{array}{l}\text { Plant } \\
\text { height } \\
(\mathbf{c m})\end{array}$ & $\begin{array}{l}\text { No. of } \\
\text { branches } \\
\left.\text { (plant }^{-1}\right)\end{array}$ & $\begin{array}{l}\text { Leaf } \\
\text { length } \\
(\mathbf{c m})\end{array}$ & $\begin{array}{l}\text { Leaf yield } \\
\left.\text { (g plant }^{-1}\right)\end{array}$ \\
\hline $\mathbf{T}_{1}$ & 18.6 & 4.33 & 3.50 & 63.08 \\
$\mathbf{T}_{2}$ & 17.2 & 4.33 & 3.67 & 59.80 \\
$\mathbf{T}_{3}$ & 16.7 & 3.00 & 3.23 & 53.40 \\
$\mathbf{T}_{4}$ & 15.6 & 3.67 & 3.03 & 51.23 \\
$\mathbf{T}_{5}$ & 22.8 & 6.33 & 4.10 & 80.93 \\
$\mathbf{T}_{6}$ & 21.6 & 5.33 & 3.90 & 71.40 \\
$\mathbf{T}_{7}$ & 14.3 & 2.67 & 2.37 & 41.60 \\
SE.d & 0.80 & 0.69 & 0.233 & 5.28 \\
CD (0.05\%) & 1.84 & 1.48 & 0.501 & 11.33 \\
\hline
\end{tabular}


The treatment $\mathrm{T}_{5}$ (Vermicompost $@ 2.5$ tha $^{-1}+$ Humic Acid@0.3 $\%$ ) recorded higher number of leaves per plant values (61.79) when compared to other treatment. It was closely followed by the treatment $\mathrm{T}_{6}$ (Vermicompost@2.5tha ${ }^{-1}+$ Panchagavya@3\%)which recorded 56.81 respectively. Among the treatments, the treatment $\mathrm{T}_{5}$ (Vermicompost@2.5tha ${ }^{-1}+$ Humic Acid@0.3\%) recorded higher leaf length $(4.10 \mathrm{~cm})$ respectively and it was followed by the treatment $\mathrm{T}_{6}$ (Vermicompost@2.5 tha-1+Panchagavya@3\%) (3.90cm respectively).

In this study, significant to highly significant influence on leaf width was showed by the organic manures. Among the different treatments, the treatment $\mathrm{T}_{5}$ (Vermicompost@2.5 tha $^{-1}+$ Humic Acid@0.3\%) registered higher leaf length $(3.27 \mathrm{~cm}$ respectively). It was followed by the treatment $\mathrm{T}_{6}$ (Vermicompost@2.5 tha $^{-1}+$ Panchagavya@3\%) which showed $3.07 \mathrm{~cm}$. Meanwhile, the least leaf width $2.47 \mathrm{~cm}$ were registered by the treatment $T_{7}$ (control).

The higher leaf yield $80.93 \mathrm{~g} \mathrm{plant}^{-1}$ were recorded by the treatment $\mathrm{T}_{5}$ (Vermicompost @2.5tha ${ }^{-1}+$ Humic Acid @0.3\%). This was followed by the treatment $\mathrm{T}_{6}$ (Vermicompost @2.5 tha ${ }^{-1}$ Panchagavya@3\%) with the leaf yield values of $71.40 \mathrm{~g} \mathrm{plant}^{-1}$. However, the lowest leaf yield was observed by the treatment $T_{7}$ (control). Among the different treatment, the highest estimated leaf yield were registered by the treatment of $\mathrm{T}_{5}$ (Vermicompost@2.5 tha $^{-1}+$ Humic Acid@0.3\%) estimated leaf yield of 20.23 tha $^{-1}$. It was followed by the treatment $\mathrm{T}_{6}$ (Vermicompost@2.5tha ${ }^{-1}+$ Panchagavya@3\%). The lowest estimated leaf yield was recorded by the treatment $\mathrm{T}_{7}$ (control) with the values of 10.04 tha $^{-1} \mathrm{~s}$ (Figure 1) (Figure 2).

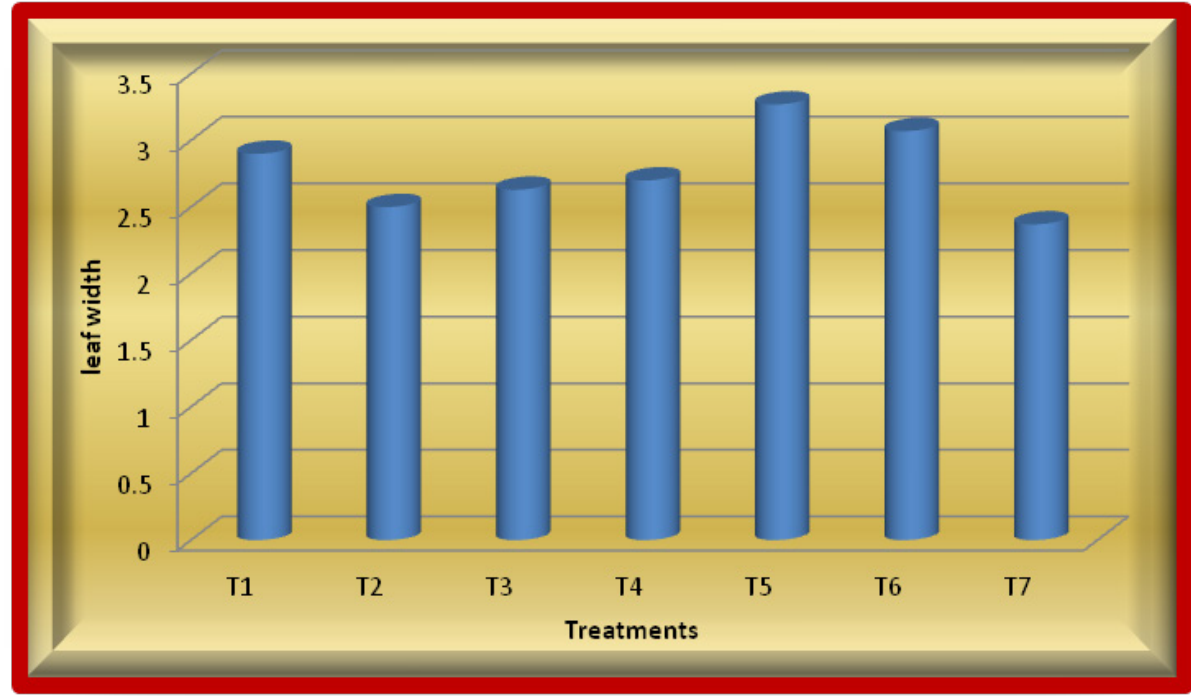

Figure I Effect of organic manure on growth, yield and quality on leaf width $(\mathrm{cm})$ of mint.

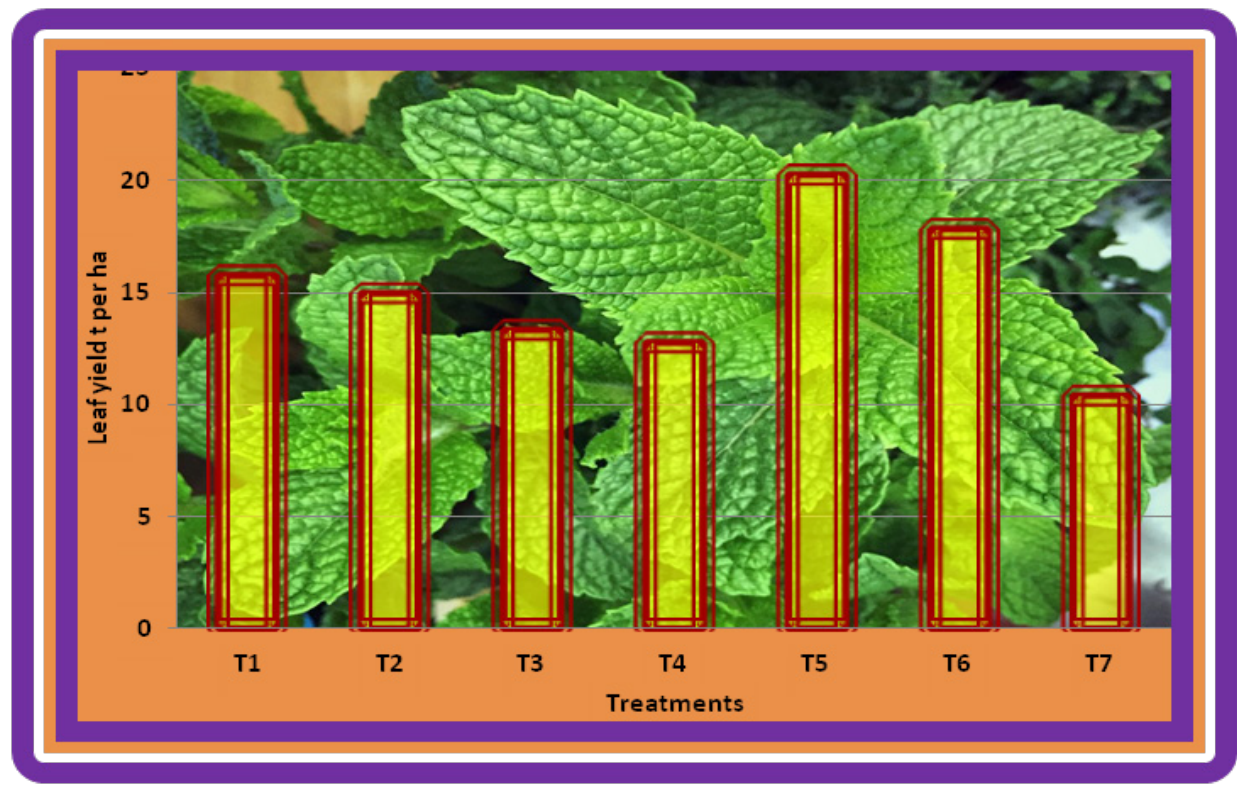

Figure 2 Effect of organic manure on growth, yield and quality on estimated green leaf yield (kg per hectare) of mint. 


\section{Discussion}

The leaves, being the economic part of mint organic manures is practiced. The organic manures viz, farmyard manures, coirpith, vermicompost, humic acid and panchagavya significantly influence the new growth and yield of fresh leaves. Several workers have reported that the organic manures resulted in increased growth, yield and quality of horticultural crops.

The chemical fertilizers are not only short supply but also expensive in developing country like India. The important of organic sources as nutrition for the growth of medicinal plant in immensely felt among the scientist and farmers. Farmyard manure, Vermicompost and coirpith compost could contribute much towards the fertility status of soil and they are the right substitute to minimize the use of chemical fertilizers. The important of organic manures has been well recognized in the cultivation of medicinal plants long back. Many farmers using this manures on wild scale for cultivation of medicinal plants.

The increase in growth parameters due to application of vermicompost may be due to the presence of growth substances, nitrogen fixers, other essential nutrients and also due to higher phosphorus by a symbiotic mycorrhizal association as reported by (Bano et al. 1987). Incorporation of vermicompost promotes the lush growth of plants which may be due to the presence of plant growth promoters like auxins and cytokinins in vermicompost (Radha et al. 1986), which are responsible for cell division and cell elongation. Vermicompost contains major and micro nutrients in plant available form along with enzymes, antibiotic, vitamins, growth hormones and beneficial microorganisms and have definite advantage over the other organic manure with respect to yield and quality.

The results indicated that combined application of vermicompost at 2.5 tper ha+humic acid 0.3 per cent which recorded higher plant height. The increase in growth parameters due to application of vermicompost may be due to the presence of growth substance, nitrogen fixers other essential nutrient and also due to higher phosphorous fertilization by a symbiotic mycorrhizal association as observed by Chaudhary et al. The results of the present study clearly indicated that the foliar application of humic acid significantly increased the plant growth characters. Zaghloul et al. ${ }^{2}$ reported that spraying of humicacidtoThujaorientalis plants hadincreased the more growth when compared with other treatmentswhich might be due to the direct effect of humic acid on solubilization and transport of nutrients.

In the present study among the organic manures recorded significantly higher number of secondary branches per plant. Among the different treatments, the treatment $\mathrm{T}_{5}$ (Vermicompost@2.5tha 1+Humic Acid@0.3\%)were registered highest number of branches and number of leaves per plant. Foliar application of humicacid@0.3per cent also exhibited significant influence on improvement of number of secondary branches and number of leaves per plant which might be due to the application of humic acid that would have increased the soil fertility due to increase availability of nutrients/elements as reported by David et al. ${ }^{3}$ and Hartwigson et al. ${ }^{4}$ Similar findings were also made by Eslah and El-hefny (2010) in cowpea.

Among the growth determining traits, leaf length, leaf width and number of leaves per plant was significantly influenced by the organic manures. Among the treatments, the treatment $\mathrm{T}_{5}$ (Vermicompost@2.5tha ${ }^{-1}+$ Humic Acid@0.3\%) were registered higher leaf length, leaf width and number of leaves per plant. The reasons for highest number of leaves and leaf area was due to enhanced release of nitrogen from the growth promoting substances produced by the microbes present in vermicompost might have resulted in the induction of leaf length, leaf width and more leaves. To elucidate the effect of humic substances, several hypotheses suggesting the formation of a complex between these substances and mineral ions, their involvement in the enhancement of enzyme catalysis, their influence of stimulating respiration, photosynthesis and nucleic acid metabolism and their hormonal activity was reported by Muscolo et al. in Dacus carota.

Among the different organic manures, Vermicompost@2.5 tha ${ }^{1}+$ Humic Acid@0.3\% $\left(\mathrm{T}_{5}\right)$ showed significantly higher green leaf yield. Vermicompost improve the soil physical condition and promotes organic matter, which in turn, produce organic acids, which inhibits particularly IAA oxidase enzyme, resulting in enhancing the promotive effect of auxin-IAA, which has direct effect on plant growth, herbage yield. In cucumber, Rauthan et al. ${ }^{5}$ proved that application of humic acid had improved the growth of foliage and roots by increased cell elongation and increased water uptake by increased plant roots as well as root systems and increased nutrients uptake, increased leaf surface area.

\section{Acknowledgments}

None.

\section{Conflicts of interest}

Author declares that there is no conflict of interest.

\section{References}

1. Panse VG, Sukhatme PV. Statistical methods for agricultural workers. Rev Edn ICAR. New Delhi; 1995.

2. Zaghloul SM, FEM El Quesni, AAM Mazhar. Infulence of Potassium humate on growth and chemical constituents of (Thujaorientalis L) seedlings. Ozean J Appl Sci. 2009;2(1):73-78.

3. David PPPV. Nelson, DG Sanders. A humic acid improves growth of tomato seedling in solution culture. J of Plant Nutrition. 1994;7:173-184.

4. Hartwigson JA, MR Evans. Humic acid seed and substrate treatments promote seedling root development. Hort Sci. 2000;35: 1231-1233.

5. Rauthan BS, Schnitzer. Effect of a soil fulvic acid on the growth and nutrients of cucumber (Cucumis sativus) plants. Plants Soil. 1981;63:491-495. 